\title{
Experimental Studies on the Characterization of Niger Delta Smectite and its Performance as a Geochemical, Bacteriological, and Geotechnical Barrier System
}

\author{
By Davidson E. Egirani ${ }^{*}$, Nabila Shehata ${ }^{ \pm}$, Ifeoma Mary Ugwu ${ }^{*}$ \\ \& Alfred Opukumo ${ }^{+}$
}

\begin{abstract}
This paper investigated the geochemical, bacteriological, and geotechnical characteristics of a smectite clay sourced in the Niger Delta Region of Nigeria and its application as a barrier system for the containment of pollutants in aqueous systems. The smectite clay was tested for various geochemical, bacteriological, and geotechnical properties. The findings revealed that the clay type had the potential to act as a barrier system for toxic heavy metals and bacteria in aqueous systems. The hydraulic conductivity of the smectite clay under effective stress of $80 \mathrm{kN} / \mathrm{m}^{2}$ was $1.6 \times 10^{-10} \mathrm{~m} / \mathrm{s}$ to natural aqueous contaminants contained in the Gbarain watershed of the Niger Delta region of Nigeria. The Gbarain watershed contained Lead (>0.01 mg/L), Mercury $(>0.006 \mathrm{mg} / \mathrm{L})$, Manganese $(>0.4 \mathrm{mg} / \mathrm{L})$ and Escherichia coli $(>0$ cfu/l00ml). Uptake of the inorganic contaminants and inhibition of bacteria by the smectite clay was significant and increased with an increase in $\mathrm{pH}$. In conclusion, smectite clay would provide an excellent geochemical, bacteriological, and geotechnical barrier system for toxic heavy metals and bacteria migration into a watercourse.
\end{abstract}

Keywords: Characterization, smectite, performance, Niger Delta region, barrier systems

\section{Introduction}

The generation of inorganic and organic wastes in the aqueous environment is as old as the beginning of the human settlement. Metal load above the international recommended level has been observed in the Gbarain watershed of the Niger Delta region of Nigeria. The water quality, especially, groundwater in this region was contaminated with excessive metal load and bacterial infection. A 3-barrier system has been suggested to enhance the water quality using locally sourced clay in the same region.

In this study, a locally sourced smectite clay in the Niger Delta region of Nigeria (i.e., Amelem) was characterized in a laboratory using geochemical, bacteriological, and geotechnical techniques. This smectite clay used to treat aqueous toxic heavy metals and bacteria migrating into a watershed clay. Some objectives

\footnotetext{
*Lecturer/Consultant, Faculty of Science, Niger Delta University, Nigeria.

${ }^{ \pm}$Lecturer, Faculty of Postgraduate Studies for Advanced Science (PSAS), Beni-Suef University, Egypt.

Lecturer, Faculty of Science, Enugu State University, Nigeria.

'Lecturer, Faculty of Science, Niger Delta University, Nigeria.
} 
of the study include determination of adsorption efficiency of the smectite clay at different $\mathrm{pH}$, determination of the clay permeability under various effective stresses, and determination of E. coli content in samples of water obtained in the Gbarain watershed. This study, therefore, forms a critical step in a series of steps required in the containment of contaminants affecting aqueous systems.

Within the context of this paper, inorganic and organic wastes from the smelting of metals and food waste from food vendors respectively, constitute an environmental liability (Agbozu et al. 2015, Tansel and Yildiz 2011, Fuller 2018). Toxic heavy metal contaminants generated by reckless disposal of inorganic wastes has, therefore, compromised the water quality in most parts of the world. Metal and bacteriological loads besides, in the Gbarain watershed in the Niger Delta Region of Nigeria, are above recommended international limits set by the World Health Organization-(WHO). The WHO limits the contaminate values of Lead, Mercury, Manganese, and Escherichia coli in drinking water as $<0.01 \mathrm{mg} / \mathrm{L}$, $<0.006 \mathrm{mg} / \mathrm{L},<0.4 \mathrm{mg} / \mathrm{L}$, and 0 cfu per $100 \mathrm{~mL}$ of Escherichia coli, respectively (Misstear et al. 2017). Both organic and inorganic wastes dumped along the flanks of streams within the Gbarain watershed. Subsequently, metal and bacteriological pollutants exist and interact with the Gbarain watershed (Oluwapelumi 2015).

This excessive mixed load is, therefore, a problem and reduction of this load to acceptable limits has generated considerable interest to researchers. Previous methods used in waste management in the Gbarain watershed include burning, recycling, reduce, reuse, incineration, and composting (Tansel and Yildiz 2011). These procedures are not capable of reducing metal and bacteriological load to acceptable level in watercourses in the watershed. A by-product of these methods may in, addition, washed into the soil by rain, thus contaminating the surface and groundwater resources (Velenturf and Jopson 2019). All procedures mentioned previously are not capable of disinfecting water contaminated with E. coli and coliform. During disinfection, pathogenic microorganisms in the water deactivated. Disinfection of the water is by chemical and physical means (Unuabonah et al. 2018). Chemical agents such as chlorine and its compounds used in the treatment of water in this region because of their effectiveness, and low cost The introduction of these chemicals to water, however, reacts with natural water to produce disinfection by-products (DBPs), that may be carcinogenic (Unuabonah et al. 2018). Using techniques not involving the addition of chemicals, such as filtration and adsorption by clay minerals has been of great interest to the international community. Some methods and combination of methods used for treating water contaminated with inorganic pollutants include ion exchange, membrane filtration, and coagulation-flocculation-sedimentation (Fu and Wang 2011). In adsorption of inorganic pollutants, the use of clay minerals has been a subject of interest to researchers (Zaki et al. 2017, Egirani et al. 2019).

Clay minerals are readily available used in the elimination of toxic heavy metals from water (Izah et al. 2018). Clay minerals are known to do effective adsorption of pollutants and barrier their migration. This ability of clay is dependent on the structure and chemical compositions (Cantor et al. 2010). The clay mineral of the smectite group includes bentonite and is composed mainly of hydrous mag- 
nesium-calcium aluminium silicate called montmorillonite. Clay minerals possess high colloidal and plastic properties with fine particles (Murray 1999).

For effective containment of an aquatic system, adsorption of metal and bacteriological load entering it is necessary. For effective elimination of these loads, however, a combination of adsorption and establishment of barrier systems are required (Xue et al. 2012). A suitable clay barrier system provides for clean, potable water, and sustainable water resource management. A clay barrier system, therefore, provides a protective structural barrier and adsorbing geochemical medium to control the movement of contaminants (Zaki et al. 2017). The performance of a clay barrier system is measured in terms of hydraulic conductivity, and chemical properties of the clay mineral. The functionality of a clay barrier system is dependent on the type of contaminants, the geotechnical, and chemical properties of the clay barrier (Ghazizadeh and Bareither, 2018). The critical function of a barrier system is to hold back the contaminants in a manner that is protective of human health and the environment. In meeting these requirements, a clay barrier system must possess low hydraulic conductivity and high adsorption capacity (Ghazizadeh and Bareither 2018). Over time, a clay barrier system with a field hydraulic conductivity of $1 \times 10^{-9} \mathrm{~m} / \mathrm{s}$ or less as reported by Oluwapelumi (2015) satisfies the requirements. A clay-based barrier system must be able to attenuate the movement of contaminants and retard the discharge of the pollutants into watercourses. Hydraulic conductivity is controlled primarily by the structural content of the clay (Oyediran and Olalusi 2017). Various researchers have supported the view that the percentages for fines for barrier clay is from $40 \%$ and $50 \%$, and plasticity indices is from $10 \%$ and $30 \%$. For some studies involving organic contaminants, the hydraulic conductivity increased when the concentration of chemical solutions increased (Hakan et al. 2018). The decrease in the hydraulic conductivity as a contaminant introduced into the barrier system has, however, reported. This characteristic may be related to the effects of the fluid composition on the clay structure i.e. the distribution of electric charges on the surface of the clay minerals (Sipos et al. 2018).

Consistency limits (Atterberg limits) are useful indicators of clay behaviour (Liu et al. 2018a). Diverse views exist on the effect of chemicals on the consistency limits of clays (Sipos et al. 2018). Liquid limit and plastic limit increased when the concentration of inorganic contaminants increased (Madsen and Mitchell 1989). The situation was different for organic pollutants where the increase in the concentration led to a decrease in the Atterberg limits. Organic chemicals tend to shrink a diffuse double layer that surrounds clay particles (Liu et al. 2018b). An effect of organic chemicals on the liquid limit behaviour of soil was studied by (Sipos et al. 2018). A metal load-contaminated sample, in this case, had lost its cohesive nature, possibly due to the collapse of the double layer in the presence of organic chemicals. As the liquid limit and plastic limit values were correspondingly increased or decreased, there is no overall change in plasticity index values as the contaminated water introduced into the system.

The influence of $\mathrm{pH}$ on the adsorption of metal ions on Na-montmorillonite was studied (Abollino et al. 2003) and found that the adsorption of metals decreases with decreasing $\mathrm{pH}$ and vice versa. At low $\mathrm{pH}$, the hydrogen ion competes with 
the metal-load towards the external sites. A silanol ( $\mathrm{Si}-\mathrm{O}-$ ) and aluminol ( $\mathrm{Al}-\mathrm{O}-$ ) groups are less deprotonated and are less available to retain metals. Adsorption of metals increases at moderate $\mathrm{pH}$ over the $\mathrm{pH}$-adsorption edge. At high $\mathrm{pH}$ values, the metal ions showed high retention on clay mineral (Sipos et al. 2018). The clays of the smectite group montmorillonite have, therefore, used as a barrier system at waste disposal sites (Odom 1984, Missana et al. 2018).

\section{Methodology}

\section{Experimental Site Location of the Gbarain Watershed}

An area selected for this study is in a southern flank of the Niger Delta Region of Nigeria (60 2' 0" E-60 8' 0" E, and $4042^{\prime} 00^{\prime \prime} \mathrm{N}-4046^{\prime} 0 " \mathrm{~N}$ ) as shown in Figure 1. This terrain is low-lying with elevations from below sea level in a southwestern flank of the region to about $40 \mathrm{~m}$ inland.

Figure 1. Map Showing the Study Location and Sample Sites

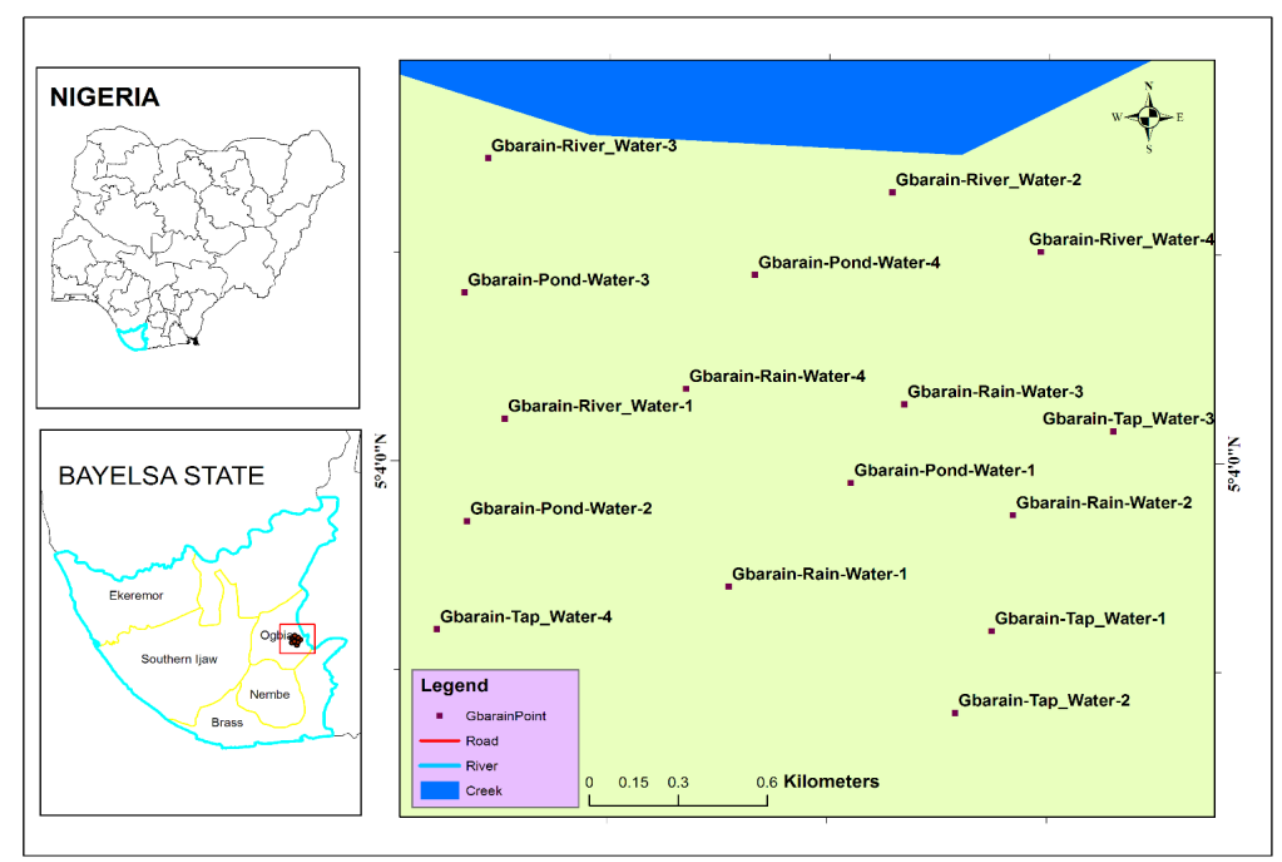

The Gbarain watershed presently hosts two waste-dump sites located along the flanks of a seasonal flow stream and seasonally waterlogged terrain. About $75 \%$ of the Niger Delta Region is associated with wetland, and annual rainfall is between 2000-3000 mm. Some parts of the Niger Delta flooded due to excessive rain, human manipulation of wet-land, and excessive release of water from Niger and Benue Rivers. An open aquifer in a watershed derived from a Benin formation that is sandy and richly drained in nature (Chukwuma and Uchenna 2018). 


\section{Experimental Methods}

The smectite clay used for tests is commonly found in the Niger Delta region of Nigeria and obtained from Dangote Industries Limited, Lagos, Nigeria. This clay is locally known as Amelem and is named smectite clay in this study. Water samples collected in triplicates from a Gbarain watershed. The sampling included 25 samples of rainwater as a control, 25 samples of surface water, and 25 samples of groundwater. All three water types were analyzed for physical, chemical, and bacteriological characteristics. However, only the contaminated groundwater selected as a material for geochemical, bacteriological and geotechnical studies. This selection was because this study was aimed at ensuring the prevention of contaminants from contaminating the groundwater.

\section{Pre-Treated Contaminated Water and Post-Treated Contaminated Water}

Triplicates of water samples were taken at each sampling point and were later transported to the laboratory for chemical and bacteriological analyses. Only analytical grade reagent and chemicals obtained from Sigma Aldrich in Dorset, United Kingdom were used in preparing reagents and standards. A collection of surface water and groundwater samples were analyzed for $\mathrm{pH}$, temperature, total dissolved solids (TDS) and electrical conductivity per standard methods Analytical methods were based on the American Public Health Association (Rice et al. 2012). The total hardness was determined by Titrimetric Method. The salinity was evaluated using Mohr's method (Rice et al. 2012). The biochemical oxygen demand (BOD) and the chemical oxygen demand (COD) were determined using titrimetric analysis and colourimetric analysis respectively (Ngang and Agbazue 2016).

\section{Determination of Adsorption Characteristics of the Niger Delta Clay}

The chemical performance of the smectite clay was studied through batch adsorption tests. The batch adsorption test is a quick method that provides information about the metal affinity of smectite clay mineral, as well as the mechanism and kinetic reaction involved. For this test, contaminated water containing $\mathrm{Fe}, \mathrm{Pb}$, $\mathrm{Hg}$ and $\mathrm{Mn}$ with a concentration of $0.25 \mathrm{mg} / \mathrm{L}, 0.06 \mathrm{mg} / \mathrm{L}, 0.019 \mathrm{mg} / \mathrm{L}$ and 0.85 $\mathrm{mg} / \mathrm{L}$, respectively were used. These metals were selected since they were above the World Health Organization limits for potable water (Misstear et al. 2017). A set of batch adsorption tests was conducted by adding $2 \mathrm{~g}$ of smectite clay in 50 $\mathrm{mL}$ of contaminated water. Samples were taken after 24 hours on an incubator shaker at $100 \mathrm{rpm}$ and ambient temperature. This time was adequate to reach equilibrium (Shafiq et al. 2018). After shaking, every mixture was centrifuged and filtered using a filter with a $0.45 \mu \mathrm{m}$ pore size. The concentrations of $\mathrm{Fe}, \mathrm{Pb}, \mathrm{Hg}$, and Mn before and after the adsorption tests were analyzed using the atomic absorption spectroscopy (AAS). Subsequently, the adsorption capacity was determined from the following linear equation (1):

$$
Q_{t}=\left[C_{0}-C_{t}\right] \frac{V}{m}
$$


Here, Co equals the initial metal concentration $\left(\mathrm{mgL}^{-1}\right)$ at time $\mathrm{t}=0, \mathrm{C}_{\mathrm{t}}$ equals the metal concentration $\left(\mathrm{mgL}^{-1}\right)$ at time $\mathrm{t}, \mathrm{V}$ equals the volume of adsorbent suspension $(\mathrm{L})$ and $\mathrm{m}$ is the weight of the adsorbent $(\mathrm{g})$. Thermal regeneration of the spent smectite clay was carried out by treating it with $1 \mathrm{M}$ nitric acid, thus, resulting in $60 \%$ regain. The extracted clay was heated to $500^{\circ} \mathrm{C}$ for $24 \mathrm{~h}$ (Shahadat and Isamil 2018).

Determination of Geotechnical Properties of the Niger Delta Clay

The particle size analysis was done using LS 13320 Coulter Laser Diffraction particle size analyzer (Blott and Pye 2006). The hydraulic conductivity test was conducted on the smectite clay following the procedures described by Tong and Shackelford (2016) using a falling headwater constant tailwater system. Diameter and height of the clay sample were $60 \mathrm{~mm}$ and $40 \mathrm{~mm}$ in the permeability test, respectively. A hydraulic conductivity test of the smectite clay using rainwater as control was also conducted. The index properties measured according to the D7263-09 and ASTM 2018.

Bacteriological Analysis of the Contaminated Water and Post Contaminated Treated Water

A quantitative bacteriological analysis was conducted to determine the total coliforms and Escherichia coli (Hachich et al. 2012). A total bacterial count was determined by the use of the standard plate counting (SPC) method. An Escherichia coli assay was evaluated by preparing and sterilizing them with ethanol. The plate was removed after $24 \mathrm{~h}$ and perfect circled colonies were identified as Escherichia coli (E. coli) and other colonies were counted as the total coliform. In details, water samples filtered and retained on a membrane filter were removed to the culture medium (mTEC for E. coli. in a Petri plate and incubated at ambient temperature $\left(35^{\circ} \mathrm{C}\right)$ for $2 \mathrm{~h}$. This process was followed-up by incubation at $44^{\circ} \mathrm{C}$ for 24 $\mathrm{h}$ for E. coli. The colonies that developed magenta colour on mTEC media were counted using the unaided eye as E. coli. Their counts were expressed in cfu/100 $\mathrm{mL}$ of the water ((Izah et al. 2018, Hachich et al. 2012).

\section{Results}

\section{Characterization of the Niger Delta Clay}

This clay has $\mathrm{SiO}_{2}(54 \%), \mathrm{Al}_{2} \mathrm{O}_{3}(17 \%), \mathrm{Fe}_{2} \mathrm{O}_{3}(5.2 \%), \mathrm{CaO}(1.5 \%), \mathrm{MgO}$ (2.5\%), $\mathrm{Na}_{2} \mathrm{O}(0.40 \%), \mathrm{K}_{2} \mathrm{O}(1.5 \%)$, Moisture content $(9.3 \%)$, Loss on Ignition $(15 \%)$, CEC (56 mmol/g), specific surface area $\left(414 \mathrm{~m}^{2} / \mathrm{g}\right)$, and Point of Zero Salt Effect (7.13). An x-ray diffraction spectrum, scanning electron microscopy and energy dispersive spectroscopy also, indicated smectite as the key constituent and elemental constituents of smectite clay tainted with copper (Figures $2 \mathrm{a}$ and $2 \mathrm{~b}$ ). The smectite clay had a clay content of $80 \%$ and the particle size distribution curve is provided (Figure 3) (Murray 1999). 


\section{Pre-Treated Contaminated Water and Post-Treated Contaminated Water}

Some results of physicochemical analysis of the rainwater, pretreated and post-treated contaminated water samples are presented (Table 1). In this study, the contaminated water samples contain toxic heavy metal load and bacteriological load above regional and international. The BOD and COD of the contaminated water were $7 \mathrm{mg} \mathrm{O} / 2$ and $20 \mathrm{mg} / \mathrm{L}$ respectively.

Figure 2a. X-Ray Diffraction Patterns of a Smectite Clay

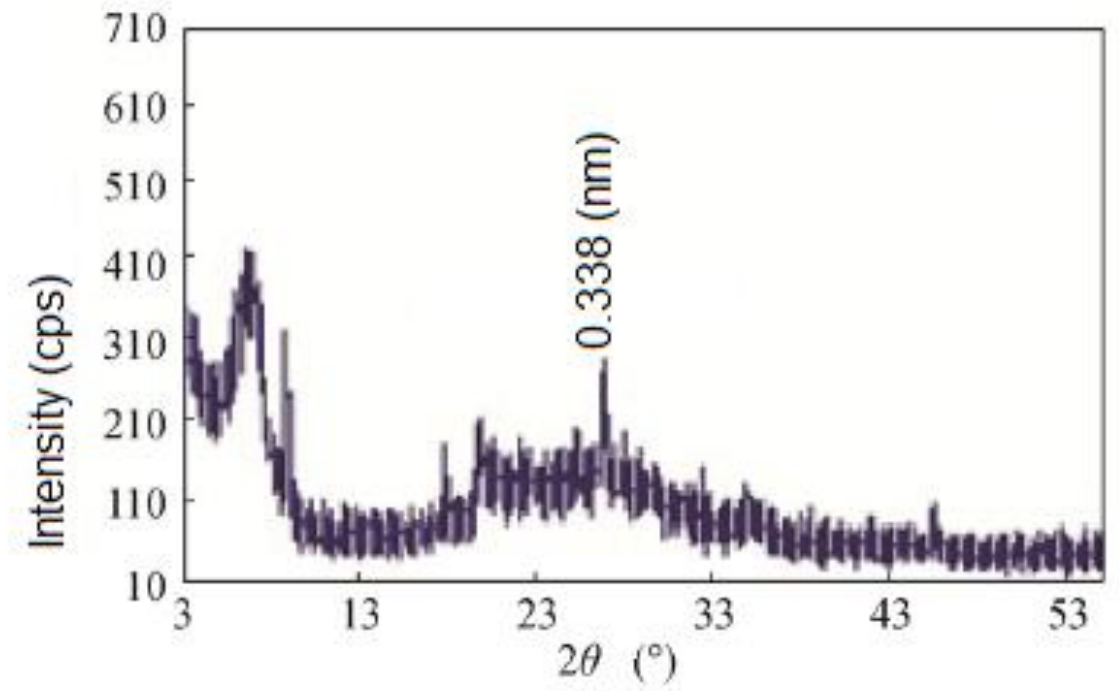

Figure 2b. SEM and EDX of Smectite Clay

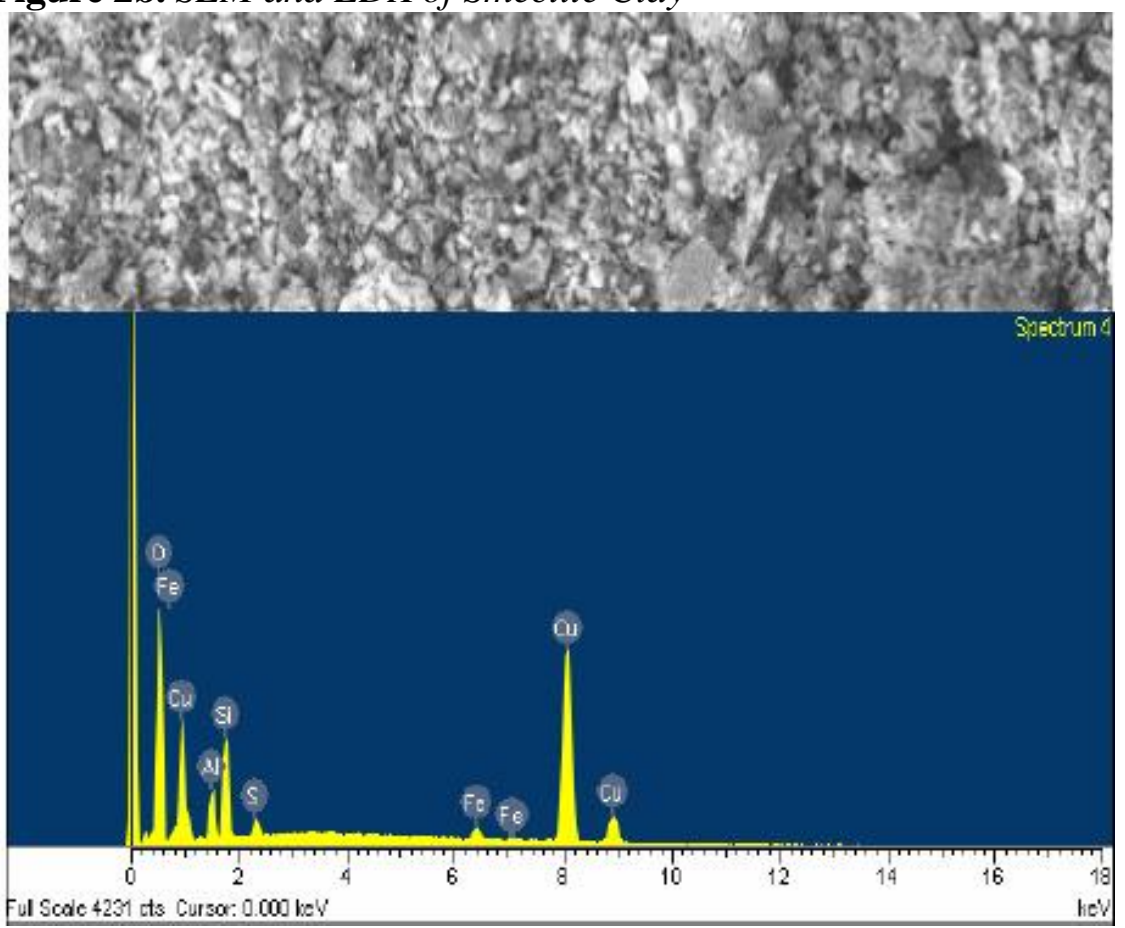


Figure 3. Coulter Laser Particle Size Distribution Curve of Smectite Clay for Rainwater and Contaminated Water

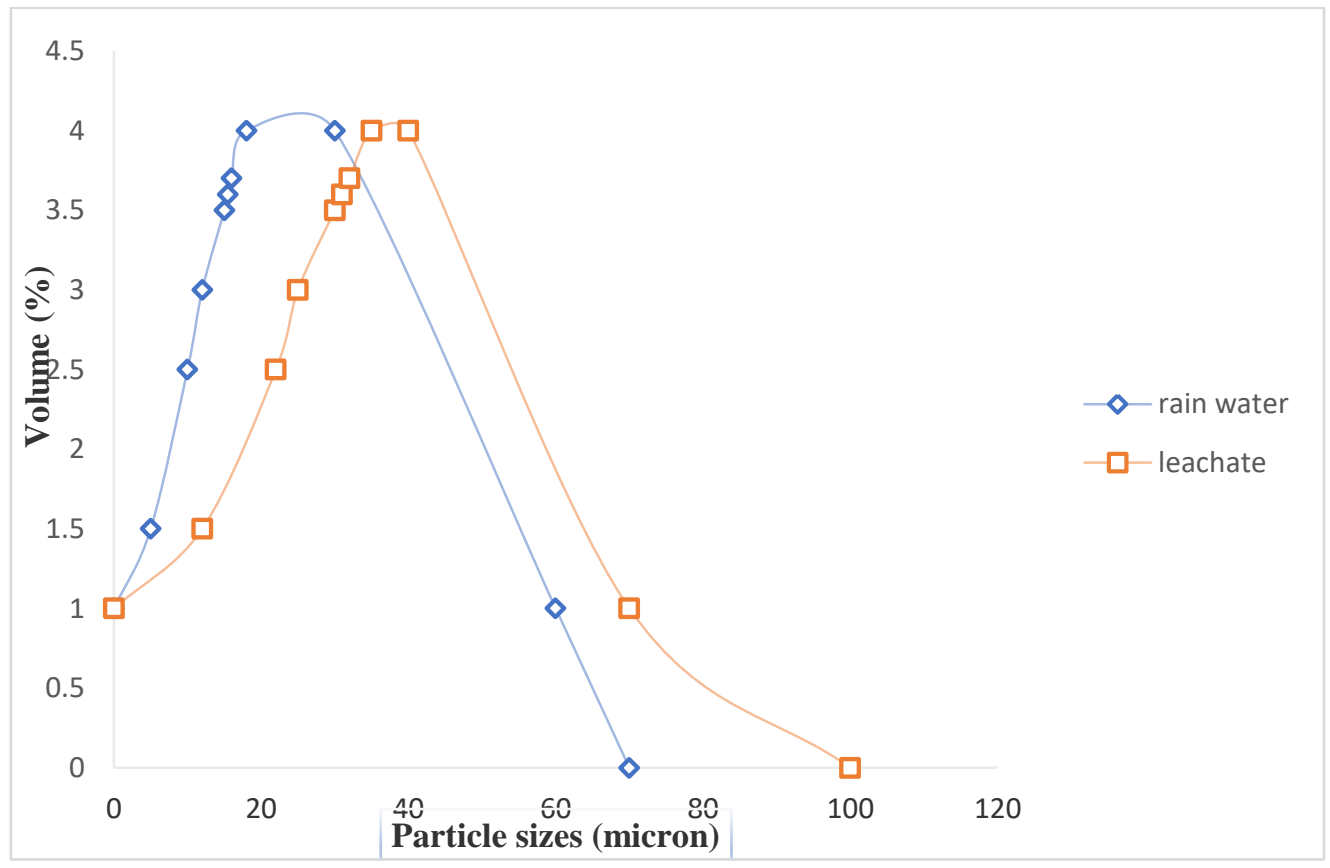

There was no statistically significant difference between groups (i.e., between particle sizes generated by rainwater and contaminated water or leachate as determined by one-way ANOVA $(F(1,20)=1.540, p=0.229)$.

Table 1. Some Index Properties of Smectite Clay Treated with Rainwater and Contaminated Water

\begin{tabular}{|c|c|c|c|c|c|c|}
\hline \multirow{2}{*}{$\begin{array}{l}\text { Smectite clay } \\
\text { treated with }\end{array}$} & \multirow{2}{*}{$\begin{array}{c}\text { Liquid } \\
\text { limit } \\
(\%)\end{array}$} & \multirow{2}{*}{$\begin{array}{c}\text { Plastic } \\
\operatorname{limit}(\%)\end{array}$} & \multicolumn{2}{|c|}{ Particle size distribution } & \multirow{2}{*}{$\begin{array}{l}\text { Plasticity } \\
\text { index }(\%)\end{array}$} & \multirow{2}{*}{$\begin{array}{l}\text { Optimum } \\
\text { water } \\
\text { content } \\
(\%)\end{array}$} \\
\hline & & & $\begin{array}{l}\text { Min diameter } \\
(\mu \mathrm{m})\end{array}$ & $\begin{array}{l}\text { Max diameter } \\
(\mu \mathrm{m})\end{array}$ & & \\
\hline Rainwater & 52 & 30 & 4 & 70 & 22 & 16 \\
\hline $\begin{array}{l}\text { Contaminated } \\
\text { water }\end{array}$ & 35 & 18 & 6 & 100 & 17 & 12 \\
\hline
\end{tabular}

There was a statistically significant difference between groups (i.e., between index properties generated by rainwater and contaminated water or leachate as determined by one-way ANOVA $(F(1,10)=0.881, p=0.024)$. A short-term evaluation of the effluent at $\mathrm{pH} 6$ indicated a reduction in groundwater contaminants. A decrease in the values of the metal load in an effluent is maybe because of the interaction of smectite clay with the contaminated water. For instance, the distribution of electric charges on a clay surface may account for interaction that led to the metal reduction. 
Table 2. Characterization of Water in the Study Location

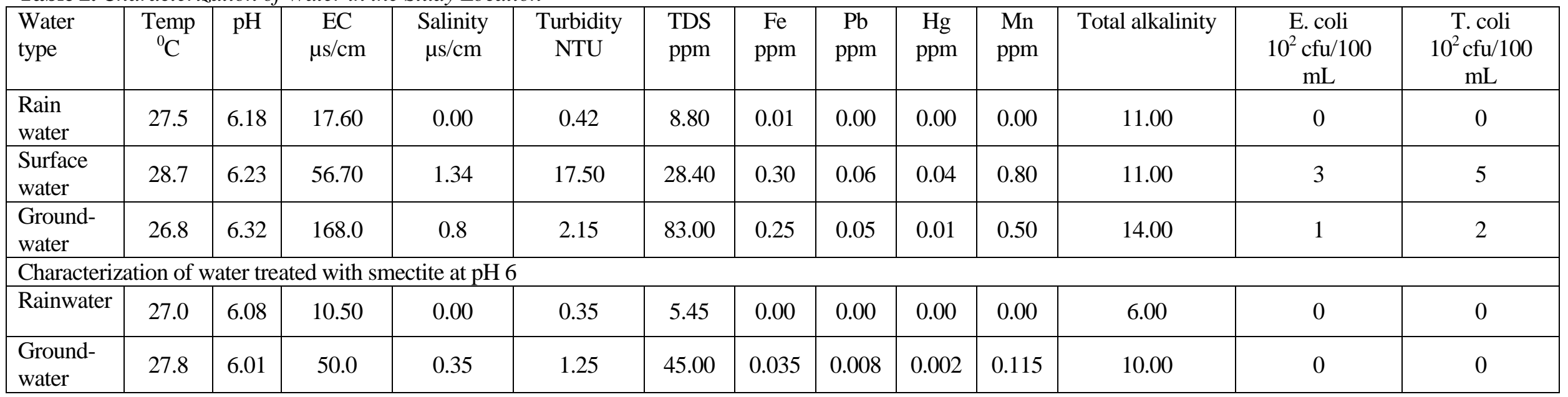


There was no statistically significant difference between groups was determined by one-way ANOVA $(\mathrm{F}(4,15)=2.055, \mathrm{p}=0.138)$. A Tukey post hoc test revealed that the metal concentration for treated water was statistically significantly lower after taking treated rainwater $(4, \mathrm{p}=0.000)$, and treated contaminated groundwater $(4, \mathrm{p}=0.04)$.

Bacteriological Analysis of Contaminated Water and Post-Treated Contaminated Water

Some results for bacteriological analysis of rainwater, pre-treated contaminated water and post-treated contaminated water are presented (Table 2). Complete elimination of E. coli and Total coliform load were observed.

\section{Discussion}

Adsorption Performance of the Niger Delta Clay Interacted with Contaminated Water

Some results for the adsorption test based on $2 \mathrm{~g}$ of smectite clay and THMs water at $\mathrm{pH}=6$ is presented (Figures 4-5). Adsorption capacity of the smectite clay over the range of $\mathrm{pH}$ investigated (i.e., $\mathrm{pH}=4-8)$ revealed $\mathrm{Fe}(82-86 \%), \mathrm{Pb}(92-$ 94\%), Hg (76-87\%), Mn (59-74\%).

Figure 4. Plot of Adsorption Efficiency versus pH of Contaminated Water using 2 $g$ of Smectite Clay

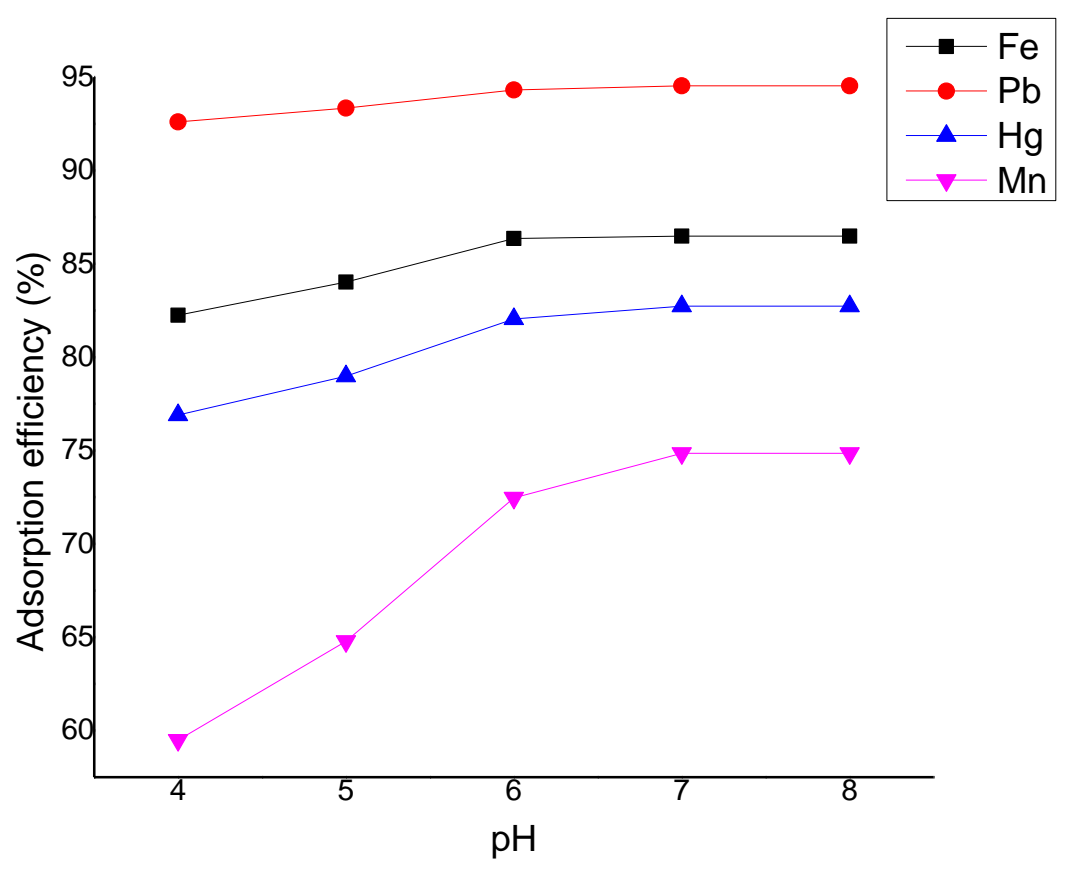


There was a statistically significant difference in adsorption efficiency between groups of heavy metals as determined by one-way ANOVA $(\mathrm{F}(3,16)=$ $35.83, \mathrm{p}=0.00)$. A Tukey post hoc test revealed that the efficiency of adsorption was not statistically significantly different between subsets of heavy met$\operatorname{als}(\mathrm{p}=1.000),(\mathrm{p}=0.292)$, and $(\mathrm{p}=1.000)$.

Figure 5. Plot of Adsorption Capacity versus Solid Concentration of Smectite Clay at $\mathrm{pH} 6$

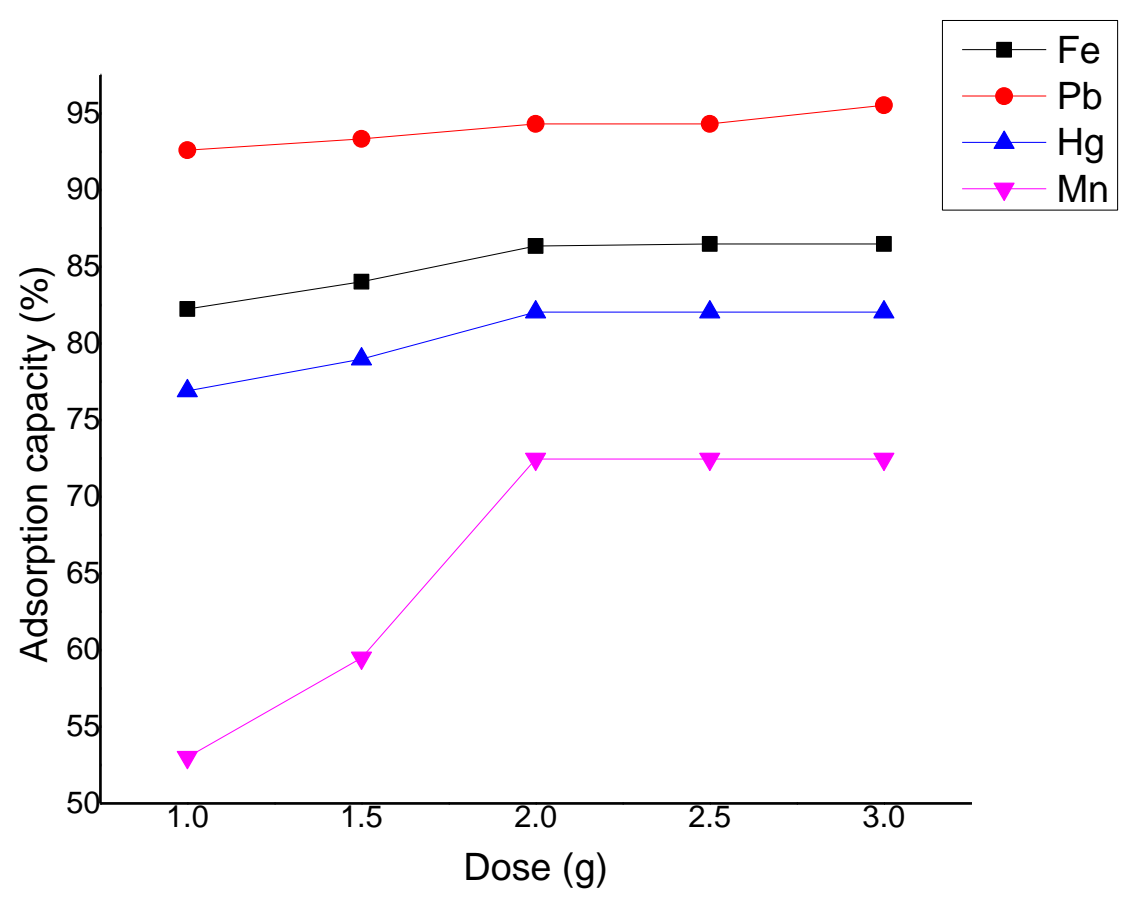

There was a statistically significant difference in adsorption efficiency between groups of heavy metals as determined by one-way ANOVA $(\mathrm{F}(3,16)=29.052, \mathrm{p}=0.00)$. A Tukey post hoc test revealed that the efficiency of adsorption was not statistically significantly different between subsets of heavy metals $(\mathrm{p}=1.000),(\mathrm{p}=0.442)$, and $(\mathrm{p}=1.000)$.

Uptake of inorganic pollutants by the smectite clay was found to be significant and increased with increased $\mathrm{pH}$. At $\mathrm{pH}=6$ and over the range of solid concentration investigated (i.e., $1-3 \mathrm{mg} / \mathrm{L}$ ), the percentage of adsorption increased as solid concentration was increased. At $\mathrm{pH}=6$ and $2.5 \mathrm{~g} / \mathrm{L}$, the percentage of adsorption was $\mathrm{Fe}(86.48 \%), \mathrm{Pb}(94.53 \%), \mathrm{Hg}(82.72 \%)$, and $\mathrm{Mn}$ (74.84\%).

The thermal regeneration of the spent smectite clay revealed a regain of $60 \%$ adsorption capacity. Thermal heating of the extracted smectite clay provided a $90 \%$ removal efficiency.

Some results indicated that the adsorption capacity of the smectite clay increased with increase in $\mathrm{pH}$. These results conform to the chemical properties of smectite clay (Kloprogge et al. 1999). 
The smectite clay adsorption mechanism was mainly based on their surface or ionic charge. The smectite clay was occupied by cations, and its surface was highly hydrophilic and $\mathrm{pH}$-independent. The metals in contaminated water, therefore, interacted with the smectite clay and became adsorbed by ion exchange. The $\mathrm{pH}$ value of the reacting environment was one of some critical factors that determinized an interaction of the smectite clay with metal ions contained in the contaminated water (Scalia et al. 2018).

An increase in adsorption as $\mathrm{pH}$ was increased suggests that the ionic species of an inorganic contaminant was more readily adsorbed than the less ionic species. A significant role played by hydrophilicity was also observed from the $\mathrm{pH}$ effects. This phenomenon generally favoured adsorption because $\mathrm{pH}$ was high enough to ensure that a charged protonated species dominated a reaction process. Hydraulic conductivity of the smectite clay was governed by the chemical composition of the contaminated water and its $\mathrm{pH}$. An increase in hydraulic conductivity of compacted natural clays occurred when a permeant liquid was an organic pollutant (Naka et al. 2012).

In this study using inorganic pollutants, a decrease in $\mathrm{pH}$ increased the hydraulic conductivity of the smectite clay increase in $\mathrm{pH}$, therefore, decreased the hydraulic conductivity of the smectite clay. At low $\mathrm{pH}$, the smectite clay possesses hydrophilic characteristics and hydrogen ion competes with metals contained contaminated-groundwater at reactive sites. Some silanol ( $\mathrm{Si}-\mathrm{O}-$ ) and aluminol (AlO-) groups also, became less deprotonated and less available (Naka et al. 2012, Delavernhe et al. 2018). At high $\mathrm{pH}$ values, the metal ions were highly adsorbed by the smectite clay.

\section{Geotechnical Performance of the Niger Delta Clay Interacted with Contaminated Water}

The smectite clay used in this study possesses hydraulic conductivity lower than $1 \times 10^{-9} \mathrm{~m} / \mathrm{s}$ and a high Cation Exchange Capacity and therefore, met the requirements for use as a barrier system. As the moisture content of the smectite clay changes from dry to wet of optimum, some fabrics of the smectite clay particles tended to change from a flocculated to a dispersed arrangement because of compaction. Higher effective stress produced closer alignment of particles along the failure surface thereby, yielding a decrease in the voids that conducted flow thus, lowering the hydraulic conductivity at higher effective stress (Oyediran and Olalusi 2017). This smectite clay demonstrated a capacity to attenuate the movement of contaminants and prolong the release of a metal load-bearing contaminated water.

Some results for short-term hydraulic conductivity evaluation are presented (Figure 6). This plot indicated that hydraulic conductivity of the smectite clay decreased when contaminated water was introduced into a clay mineral system. 
Figure 6. Plot of Effective Stress versus Hydraulic Conductivity of Smectite Clay based on Rainwater and Contaminated Water

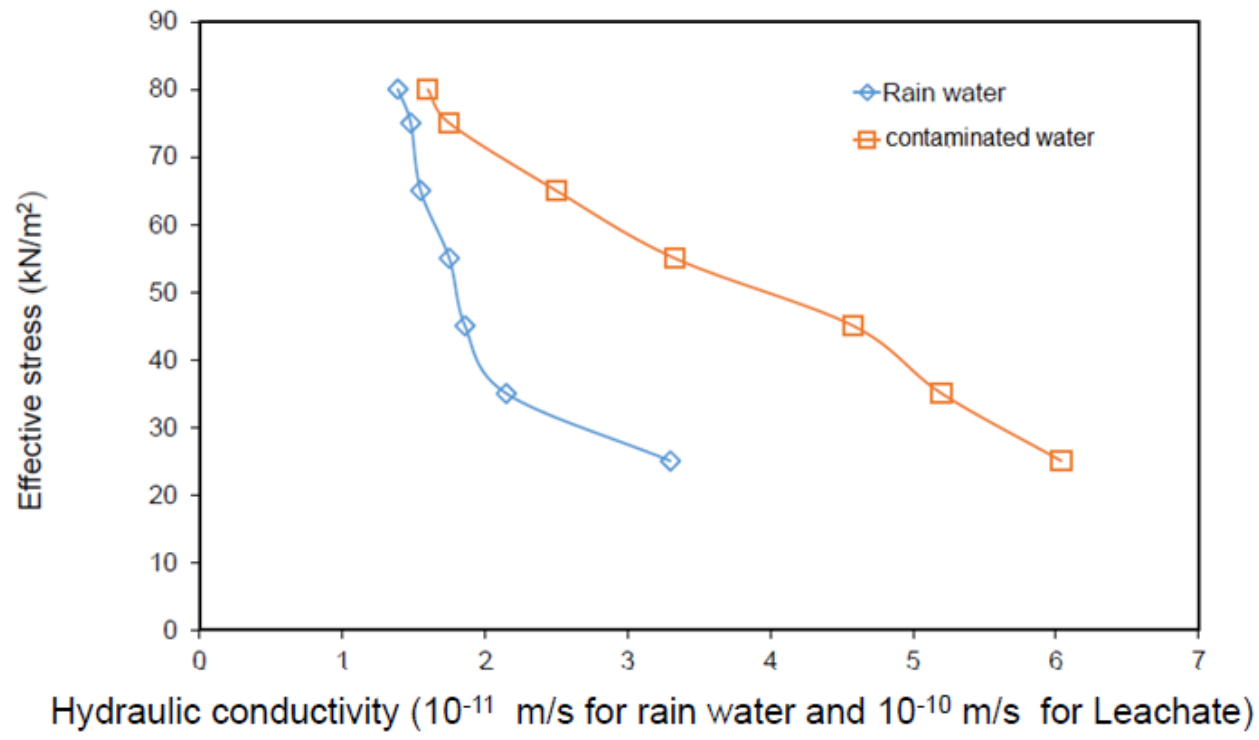

There was a statistically significant difference in hydraulic conductivity between groups was determined by one-way ANOVA $(F(1,12)=5.43, p=0.038)$. Hydraulic conductivity of the smectite clay based on rainwater as the control was higher than that based on contaminated water. Hydraulic conductivity of the smectite clay meets the requirements for a clay barrier (i.e., $1 \times 10^{-9} \mathrm{~m} / \mathrm{s}$ or less). This characteristic is, however, in contrast with previous studies for hydraulic conductivity of geosynthetic clay liner that increased over time when permeated with acid rock drainage (Naka et al. 2012). This difference may be since this study was a short evaluation. A clay void ratio decreased as effective stress was increased. A void ratio based on rainwater was also, higher than that based on contaminated water (Figure 7). Some results for Atterberg limits are presented (Table 1). Atterberg limits decreased when the smectite clay has interacted with the contaminated water. An overall plasticity index of the smectite clay was, however, within the limits of $10-30 \%$ required for clay barriers.

From the experimental results, an uptake of the metal load contained in water was dependent on the chemical and geotechnical properties of the smectite clay. The smectite clay used in this study was a powdered type with a high specific surface area and high micron range particle size. The structure, chemical composition, exchangeable ion type, and small crystal size of smectite clays are several unique features that have influenced the chemical and geotechnical properties of the smectite clay. 
Figure 7. Plot of Consolidation versus Void Ratio based on Rainwater and Contaminated Water

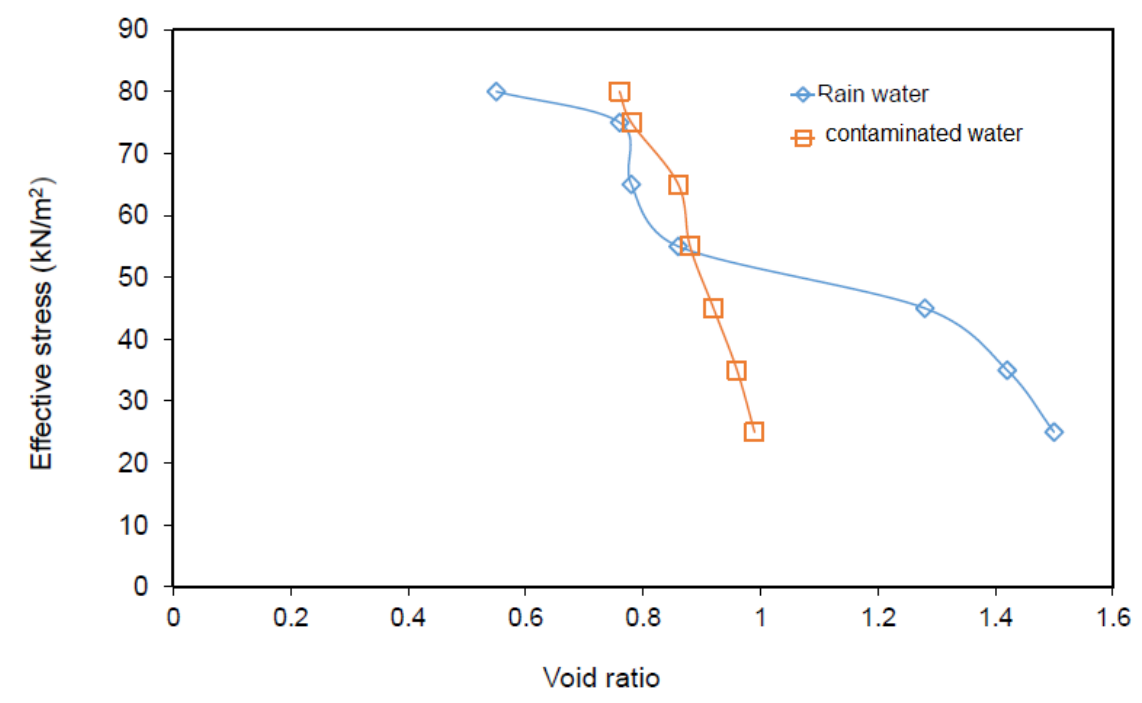

There was no statistically significant difference in void ratio between groups as determined by one-way ANOVA $(\mathrm{F}(1,12)=0.980, \mathrm{p}=0.342)$. These properties include large chemically active surface area and a high cation exchange capacity. Because of these properties, the smectite clay used in this study was able to remove toxic metal ions in the contaminated water (Liu et al. 2018b). Therefore, this smectite clay hydrates uniformly from the outer surfaces towards the centre. These characteristics further, lower the hydraulic conductivity of the smectite clay used in this study (Liu et al. 2018b). These qualities result in the rapid development of an effective barrier system. The smectite clay generates high colloidal fraction when in contact with water and this characteristic enhances the adsorption characteristic of the smectite clay (Missana et al. 2018).

\section{Performance of the Niger Delta Clay on the Bacteriology of the Contaminated Water}

There was no statistically significant difference in bacterial removal between groups was determined by one-way ANOVA $(\mathrm{F}(4,5)=0.666, \mathrm{p}=0.643)$. However, individual groups exhibited a non-statistically significant difference in bacterial removal. Elimination of the bacterial load took place by adhesion as provided in a previous study (Nandakumar et al. 2019, Dong 2012). The nature of the smectite clay surface and microbial cell surfaces are important in determining how some bacteria adhere to the smectite clay surfaces. This adhesion is a prelude to understanding the mechanism of removal of these bacteria from water (Liu et al. 2018b). An adhesion process was controlled by both chemical and physical interactions of the surface of the smectite clay and bacteria. An outcome of these contacts is dependent on a complex interaction between these bacteria and substrate surfaces. 


\section{Comparison of Performances}

The smectite clay (Amelem) performed best as a bacteriological barrier, providing complete elimination of the E. coli in the contaminated water. The performance of this indicator is followed by the geotechnical characteristics of the smectite clay, thus providing a hydraulic conductivity of $1.6 \times 10^{-10} \mathrm{~m} / \mathrm{s}$. The geochemical and adsorption characteristics of the smectite clay were $\mathrm{pH}$-dependent, thus providing an adsorption efficiency of $\approx 95 \%$.

\section{Conclusions}

In this study, a well-characterized locally sourced clay from the Niger Delta Region of Nigeria (Niger Delta Clay), was tested as a three-barrier system. The adsorption, geotechnical and bacteriological properties of the smectite clay provide statistically significant performance in the reduction of toxic heavy metals and bacterial load found in the Gbarain watershed of the Niger Delta Region of Nigeria. The findings reveal that the short-term evaluation of a simulated effluent indicated a reduction in toxic heavy metals and bacteriological load contained in contaminated-groundwater to safe limits based on WHO's standard.

Uptake of some inorganic pollutants by the smectite clay was found to be significant and increased with an increase in $\mathrm{pH}$ and dose of the adsorbent. The smectite clay, therefore, provided an excellent three- barrier system to the migration of metal load and bacteriological load contained in aqueous systems. This study was a 24-h short-term laboratory evaluation of properties related to the smectite clay as a 3-barrier system. Further studies would incorporate long-term lifetime or saturation time of the smectite clay.

\section{Acknowledgments}

The authors are grateful to the authority of the corresponding authors' institutions for the release of research allowances used for this project.

This research was funded by research allowances (SL20172018) provided by corresponding authors' Institution.

\section{References}

Abollino O, Aceto M, Malandrino M, Sarzanini C, Mentasti E (2003) Adsorption of heavy metals on Na-montmorillonite. Effect of $\mathrm{pH}$ and organic substances. Water Research 37(7): 1619-1627.

Agbozu IE, Oghama OE, Odhikori JO (2015) Physico-chemical characterization and pollution index determination of leachates from Warri waste dumpsite, Southern Nigeria. Journal of Applied Sciences and Environmental Management 19(3): 361372. 
Blott SJ, Pye K (2006) Particle size distribution analysis of sand-sized particles by laser diffraction: an experimental investigation of instrument sensitivity and the effects of particle shape. Sedimentology 53(3): 671-685.

Cantor KP, Villanueva CM, Silverman DT, Figueroa JD, Real FX, Garcia-Closas M et al. (2010) Polymorphisms in GSTT1, GSTZ1, and CYP2E1, disinfection by-products, and risk of bladder cancer in Spain. Environmental Health Perspectives 118(11): $1545-1550$.

Chukwuma OM, Uchenna OF (2018) A comparative analysis of flooding in Warri and port Harcourt urban areas of the Niger Delta region in Southern Nigeria. Arabian Journal of Geosciences 11(8): 166.

D7263-09, ASTM (2018) Standard test methods for laboratory determination of density (unit weight) of soil specimens. USA.

Delavernhe L, Pilavtepe M, Emmerich K (2018) Cation exchange capacity of natural and synthetic hectorite. Applied Clay Science 151(Jan): 175-180.

Dong H (2012) Clay-microbe interactions and implications for environmental mitigation. Elements 8(2): 113-118.

Egirani DE, Poyi NR, Wessey N (2019) Synthesis of zinc oxide-montmorillonite composite and its effect on the removal of aqueous lead ions. Acta Geochimica 38(1): 120-130.

Fu F, Wang Q (2011) Removal of heavy metal ions from wastewaters: a review. Journal of Environmental Management 92(3): 407-418.

Fuller WH (2018) Soils in waste treatment and utilization: volume i: land treatment. CRC Press.

Ghazizadeh S, Bareither CA (2018) Stress-controlled direct shear testing of geosynthetic clay liners I: apparatus development. Geotextiles and Geomembranes 46(5): 656666.

Hachich EM, Di Bari M, Christ APG, Lamparelli CC, Ramos SS, Sato MIZ (2012) Comparison of thermotolerant coliforms and Escherichia coli densities in freshwater bodies. Brazilian Journal of Microbiology 43(2): 675-681.

Hakan Ören A, Kul TÖ, Koç ME, Demirkıran H (2018) Comparison of the hydraulic conductivity of GCLs with that of bentonitic mixtures. Conference Paper. GeoChicago, August 2016, 358-367.

Izah SC, Bassey SE, Ohimain EI (2018) Ecological risk assessment of heavy metals in cassava mill effluents contaminated soil in a rural community in the Niger Delta region of Nigeria. Molecular Soil Biology 9(1): 1-11.

Kloprogge JT, Komarneni S, Amonette JE (1999) Synthesis of smectite clay minerals: a critical review. Clays and Clay Minerals 47(5): 529-554.

Liu P, Wang S, Ge L, Thewes M, Yang J, Xia Y (2018a). Changes of Atterberg limits and electrochemical behaviours of clays with dispersants as conditioning agents for EPB shield tunnelling. Tunnelling and Underground Space Technology 73(Mar): 244251.

Liu JF, Ni HY, Chen YG, Wu Y, Song SB, Cao XL et al. (2018b) Research on water retention and microstructure characteristics of compacted GMZ bentonite under free swelling conditions. Environmental Earth Sciences 77(16): 583.

Madsen FT, Mitchell JK (1989) Chemical effects on clay farbric and hydraulic conductivity. In P Baccini (ed), The Landfill. Lecture Notes in Earth Sciences. Berlin, Heidelberg: Springer.

Missana T, Alonso U, Fernández AM, García-Gutiérrez M (2018) Colloidal properties of different smectite clays: significance for the bentonite barrier erosion and radionuclide transport in radioactive waste repositories. Applied Geochemistry 97(Oct): 157-166. 
Misstear BD, Banks D, Clark L (2017) Water wells and boreholes. Chichester: John Wiley \& Sons.

Murray HH (1999) Applied clay mineralogy today and tomorrow. Clay Minerals 34(1): $39-49$.

Naka A, Katsumi T, Flores G, Inui T, Ohta T, Urakoshi T et al. (2012) Evaluation of mineral barriers against acid rock drainage. Geotechnical Engineering Journal of the SEAGS \& AGSSEA 43(3): 35-42.

Nandakumar V, Huang C, Pulgar A, Balasubramanian V, Wu G, Chandar P et al. (2019) Particle assisted removal of microbes from surfaces. Journal of colloid and Interface Science 533(Jan): 190-197.

Ngang BU, Agbazue VE (2016) A seasonal assessment of groundwater pollution due to biochemical oxygen demand, chemical oxygen demand and elevated temperatures in Enugu northern senatorial district, south east Nigeria. IOSR Journal of Applied Chemistry 9(7): 66-73.

Odom IE (1984) Smectite clay minerals: properties and uses. Philosophical Transactions of the Royal Society of London. Series A, Mathematical and Physical Sciences 311 (1517): 391-409.

Oluwapelumi OO (2015) Geotechnical characterization of some clayey soils for use as landfill liner. Journal of Applied Sciences and Environmental Management 19(2): 211-217.

Oyediran IA, Olalusi DA (2017) Hydraulic conductivity and leachate removal rate of genetically different compacted clays. Innovative Infrastructure Solutions 2(1): 46.

Rice EW, Baird RB, Eaton AD, Clesceri LS (2012) Standard methods for the examination of water and wastewater. Washington, DC, USA: American Public Health Association.

Scalia IVJ, Bohnhoff GL, Shackelford CD, Benson CH, Sample-Lord KM, Malusis MA et al. (2018) Enhanced bentonites for containment of inorganic waste leachates by GCLs. Geosynthetics International 25(4): 392-411.

Shafiq M, Alazba AA, Amin MT (2018) Removal of heavy metals from wastewater using date palm as a biosorbent: a comparative review. Sains Malaysiana 47(1): 35-49.

Shahadat M, Isamil S (2018) Regeneration performance of clay-based adsorbents for the removal of industrial dyes: a review. RSC Advances 8(43): 24571-24587.

Sipos P, Kis VK, Balázs R, Tóth A, Kovács I, Németh T (2018) Contribution of individual pure or mixed-phase mineral particles to metal sorption in soils. Geoderma 324(Aug): 1-8.

Tansel B, Yildiz BS (2011) Goal-based waste management strategy to reduce persistence of contaminants in leachate at municipal solid waste landfills. Environment, Development and Sustainability 13(5): 821-831.

Tong S, Shackelford CD (2016) Standardized hydraulic conductivity testing of compacted sand-bentonite mixtures. Geotechnical Testing Journal 39(6): 1015-1029.

Unuabonah EI, Ugwuja CG, Omorogie MO, Adewuyi A, Oladoja NA (2018) Clays for efficient disinfection of bacteria in water. Applied Clay Science 151(Jan): 211-223.

Velenturf AP, Jopson JS (2019) Making the business case for resource recovery. Science of the Total Environment 648(Jan): 1031-1041.

Xue M, Li J, Xu Z (2012) Environmental friendly crush-magnetic separation technology for recycling metal-plated plastics from end-of-life vehicles. Environmental Science \& Technology 46(5): 2661-2667.

Zaki AA, Ahmad MI, El-Rahman KA (2017) Sorption characteristics of a landfill clay soil as a retardation barrier of some heavy metals. Applied Clay Science 135(Jan): 150 167. 
